\title{
Opportunities for coppice management at the landscape level: the Italian experience
}

\author{
Paola Mairota ${ }^{(1)}$, Maria Chiara \\ Manetti ${ }^{(2)}$, Emilio Amorini ${ }^{(2)}$, \\ Francesco Pelleri ${ }^{(2)}$, Marco \\ Terradura ${ }^{(3)}$, Mauro \\ Frattegiani $^{(3)}$, Paola Savini ${ }^{(3)}$, \\ Francesco Grohmann ${ }^{(4)}$, Paolo \\ Mori ${ }^{(5)}$, Pier Giorgio Terzuolo ${ }^{(6)}$, \\ Pietro Piussi ${ }^{(7)}$
}

\begin{abstract}
Coppice silviculture has a long tradition in Italy. Societal demands have led to the development of forest management techniques for integrating wood production with other kinds of forest uses and regulations have been issued to limit forest degradation. In Italy, $35 \%$ of the national forest cover is currently managed under coppice silvicultural systems that provide $66 \%$ of the annual wood production. Fuel-wood demand is increasing and a large amount of fuelwood is currently imported in Italy. Modern coppice practices differ from those adopted in the past and may have a reduced impact on ecosystem characteristics and processes. Nevertheless, coppice silviculture has a bad reputation mostly on grounds that are beyond economic, technical and ecological rationales. Neither cessation of use nor a generalized conversion from coppice to high forest are likely to respond simultaneously to the many demands deriving from complex and articulated political and economic perspectives operating at global, European, national, regional and forest stand-level scales. Different approaches of modern silviculture to coppice successfully tested in Italy for more than a decade are illustrated. We propose to combine different options at the stand and sub-stand level, including either development without human interference or conversion to high forest, and to apply these approaches within the framework of novel forest management plans and regionally consis tent administrative procedures. This bottom-up approach represents a potential solution to the socio-economic and environmental challenges affecting coppicing as a silvicultural system.
\end{abstract}

Keywords: Biodiversity, Coppice Silviculture, Environmental Change, Landscape, Socio-economic Dynamics, Sustainable Forest Management

stands have a relatively recent origin, such as those derived from oak high forests exploited during the second half of the XIX century to provide railroad sleepers, those obtained from salvage operation carried out in sweet chestnut orchards destroyed by chestnut blight (Cryphonectria parasitica

\section{Introduction}

Coppice silviculture has a very long tradition in Italy. Some stands, still regularly coppiced, have been managed this way since several centuries without interruption (Piussi 1979, Amorini \& Fabbio 2009, Piussi \& Redon 2001). However, some
[Murr.] Barr.) in the 1940 s and 1950s, and those derived from woodlands spontaneously or purposely established on abandoned farmland for fuelwood production during recent decades (Del Favero 2000). Forest land classified as coppice in Italy currently encompasses almost $35 \%$ of the national forest cover (approximately 36,631 $\mathrm{km}^{2}$ ), yet its distribution varies between administrative units (Fig. 1 - INFC 2007). This amount has been almost stable as from the 1960s (La Marca \& Bernetti 2011). The most important species traditionally managed as coppice are deciduous oaks (Quercus spp., 33\%), European hophornbeam (Ostrya carpinifolia Scop., 17\%), beech (Fagus sylvatica L., 13\%), sweet chestnut (Castanea sativa Miller, 16\%), which are usually grown as pure stands, and the evergreen holly oak (Quercus ilex L., $10 \%$ ) which frequently grows in mixed stands (maquis). As with most (63.5\%) of the forest cover in Italy, coppice woodlands are mainly under private ownership. Nowadays, this silvicultural category is based on stools and is mainly represented by coppice with standards (76\% - INFC 2007), 16\% of which are classified as compound coppice (Perrin 


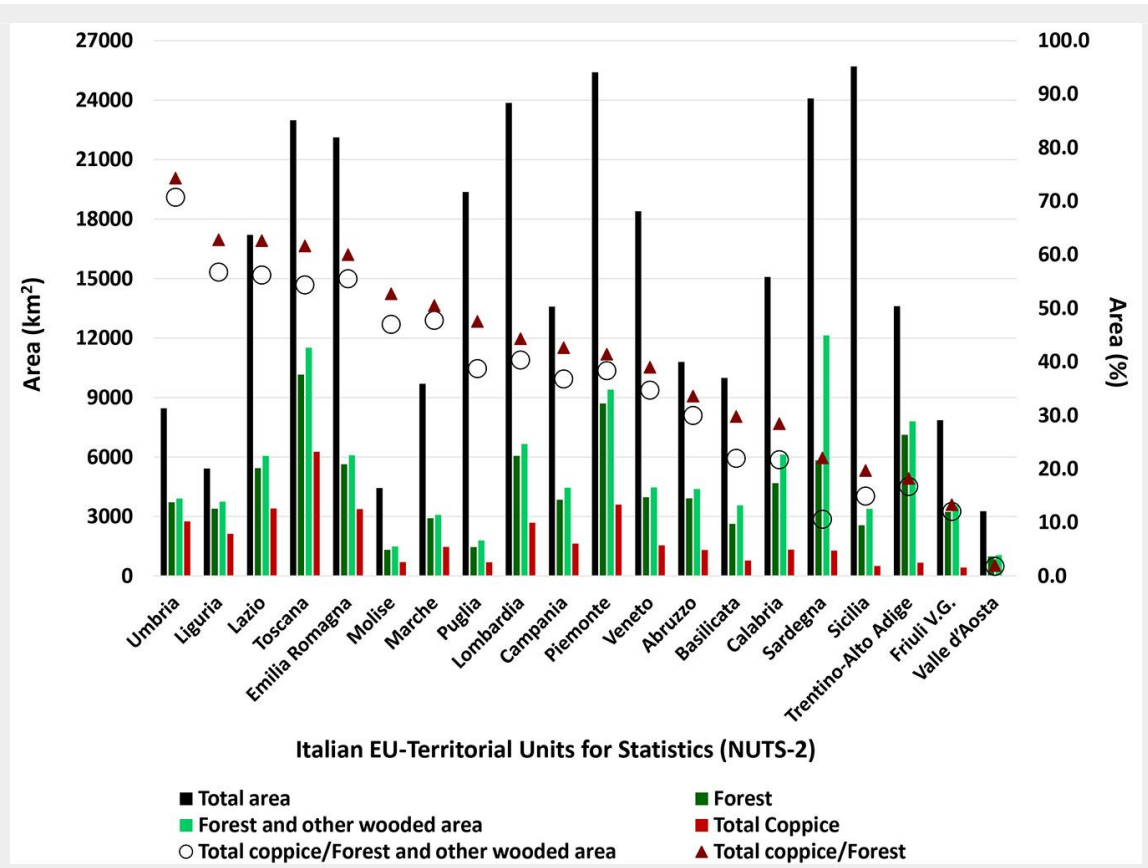

Fig. 1 - Distribution of coppices in Italy. Administrative regions (NUTS2) are ranked by the decreasing incidence of coppice over the total forest area (Source: INFC 2007).

1954, Nyland 2002) and, to a lesser extent, by simple coppice ( $24 \%$ - Fig. 2). Other forms of coppice, e.g., shredded trees and pollards, can be currently found only as relicts and/or in agricultural landscapes.

Italian coppices account for almost $19.2 \%$ of the coppices in the whole EU28 (Tab. 1), which in turn represent $83.3 \%$ and $52.1 \%$ of the coppices in the whole Europe and at the global levels, respectively (UN-ECE/FAO 2000).

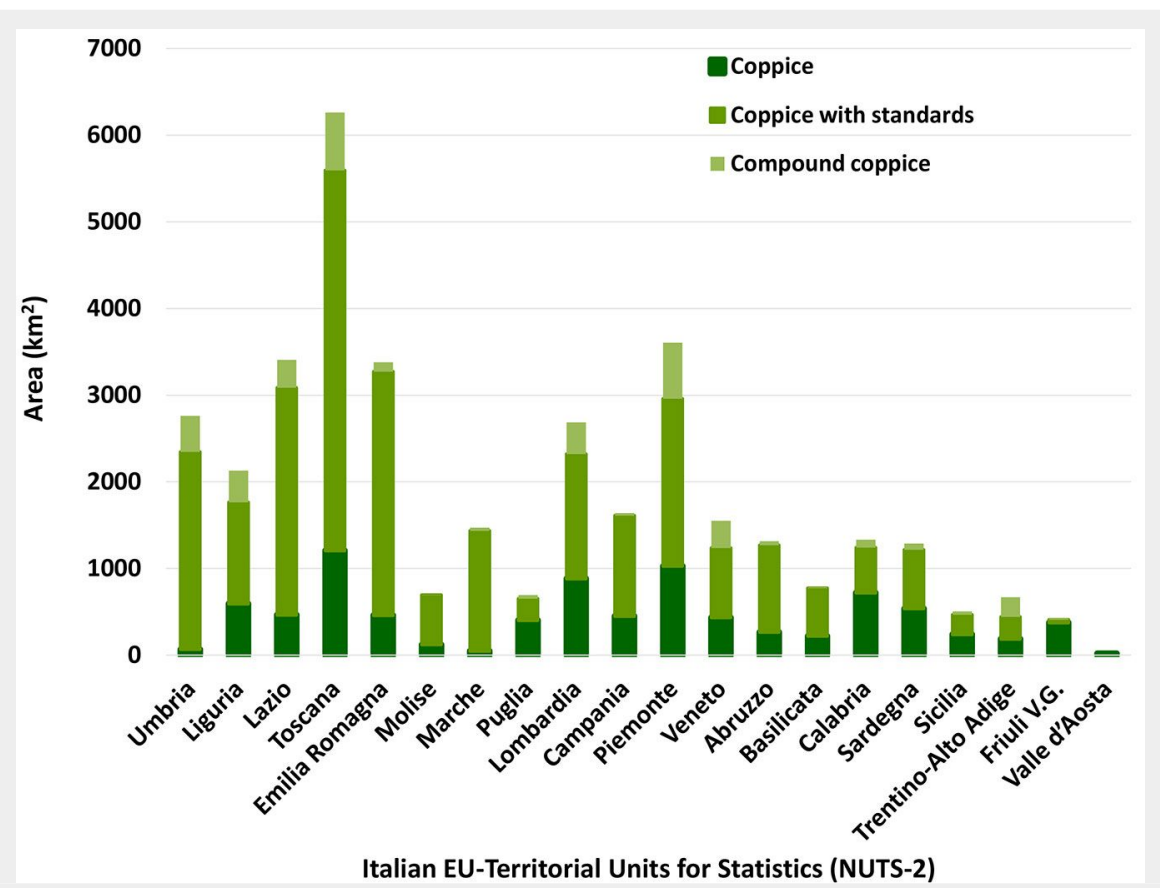

Fig. 2 - Distribution of coppices, coppices with standards and compound coppice in Italy. Administrative regions (NUTS2) are ranked by the decreasing incidence of coppice over the total forest area (see Fig. 1). Source: INFC 2007. multaneously satisfied at the operational management level (i.e., stand). Such demands encompass the whole range of ecosystem services (ES) provided by forests (Millennium Ecosystem Assessment 2005). As for most ES, the spatio-temporal domain of forest ES capacity and flow (sensu Howe et al. 2014) exceeds the stand or the individual forest, where ES are produced (service providing areas, SPAs sensu Syrbe \& Walz 2012), and involves larger socio-ecological systems (landscapes), comprised of service benefiting areas (SBAs) and services connecting areas (SCAs).

Landscapes as perceived by people, however, are formed through bottom-up processes, as they are "areas whose character is the result of the action and interaction of natural and/or human factors" (Council of Europe 2000). Thus, bottom-up planning, or collaborative planning for landscape change, is being advocated (Termorshuizen \& Opdam 2009) that is expected to result in more sustainable socio-ecological systems (Schultz et al. 2007).

This is very relevant to coppice silviculture and to Italy where: (a) many cultural landscapes across the country have been shaped by the long history of coppice forest management; (b) fuel-wood demand (approximately $17.7 \mathrm{Gg}$ in 2013 - ISTAT 2014), increasing since the mid-1970s (Piussi \& Alberti 2015), is mainly satisfied by (not always traceable) imports (Masiero et al. 2013), mostly from Eastern European and Balkan countries; (c) approximately two thirds of the country's annual forest production is represented by fuel-wood; (d) a number of constraints (e.g., reduced accessibility, absence/unresponsiveness of the owners, restrictions in protected areas) determine a reduction of utilization rates of approximately one third of the annual increment (La Marca \& Bernetti 2011, Piussi \& Alberti 2015); (e) forest management is seldom practiced due to the fragmentation of private forest properties and where still practiced is mainly carried out by individual rather than associated owners; ( $f$ ) the solutions, i.e., harvesting cessation (Fig. S1 in Supplementary material), or the generalized conversion from coppice to high forest systems (Fig. S2 in Supplementary material), more generally advocated by a large number of technicians and decision makers, are not likely to be adequate to meet multiple demands if considered in isolation at the stand level (Fabbio 2010).

We describe the state of the art of coppice silviculture in Italy with the purpose of encouraging a framework for bottom-up landscape forest planning and governance. To this end we: (i) highlight the shortcomings of past exploitation of coppice woodlands and of current silvicultural choices; (ii) illustrate different novel approaches to coppice silviculture; (iii) show the potential offered by the combination of novel and traditional silvicultural approaches; and (iv) indicate examples of strategical and tacti- 
cal options already in force and envisaged to overcome the challenges hindering its implementation.

We aim to contribute to the ongoing discussion (Spitzer et al. 2008, Vild et al. 2013, Mölder et al. 2014, Müllerová et al. 2015) on the continuation/re-establishment of coppice management in connection with both biodiversity conservation and sustainable energy production.

\section{Past and current management}

Although no generalization is possible for Italy as a whole, societal demands, driven by specific social and economic needs, have led to the integration of wood production with the provision of other kinds of forest uses and services. It is beyond doubt that outdated coppicing modes pose problems related to the structural uniformity created within and between forest harvests and to the high frequency of the disturbance pulse on the different ecosystem compartments. However, the poor reputation of coppice in ecological terms has been mostly generated by the way forests were used. Very short rotations (810 years), litter collection, tillage of soil after clear-cutting to produce agricultural crops for 2-3 years (a kind of archaic agroforestry), and unregulated grazing were the usual practices associated with coppice forestry in all forest types. Nutrient losses were quite high and erosion was unavoidable, often resulting in forest degradation. All these adverse effects are not necessarily the result of coppicing per se, but of poor management practices dictated by need and various physiographic, economic and social constraints (Fabbio 2010). Regulations have been issued through time to limit activities and disturbances, which would otherwise reduce the benefits derived from the coppice system and hinder what had been conceived and empirically demonstrated through the centuries as a sustainable wood production system. Such practices, which had been banned after the first world war (WW-I), were in fact abandoned only after WW-II, except for grazing. This more conservative use of coppice woodlands is considered effective in reducing impacts on ecosystem characteristics and processes such as the water cycle, humus loss and nutrient removal (Piussi \& Alberti 2015), particularly when carried out within the limits of the optimal ecological conditions of the dominant tree species (Del Favero 2000) and coupled with planning and implementation of appropriate harvesting and yarding operations (Pentek et al. 2008). Yet frequently the impact of prolonged multiple resource exploitation is still evident.

Three significant post WW-II benchmarks can be recognized in the history of coppice management in the generality of coppice woodlands and attitudes towards this silvicultural system in Italy. These are summarized in Tab. S1 (Supplementary material), in connection with the dynamics of the sys-

Tab. 1 - Distribution of forests, "forests available for wood supply" (FAWS), absolute values, and coppice (C) and coppice with standards (Cs) absolute and relative values, in the countries of EU28 (source: UN-ECE/FAO 2000). ( $¥$ ): indicates the maximum value in each column.

\begin{tabular}{|c|c|c|c|c|c|c|}
\hline Country & $\begin{array}{l}\text { Forest } \\
\left(\mathrm{km}^{2}\right)\end{array}$ & $\begin{array}{l}\text { FAWS } \\
\left(\mathbf{k m}^{2}\right)\end{array}$ & $\begin{array}{l}\text { C\&Cs } \\
\left(\mathrm{km}^{2}\right)\end{array}$ & $\begin{array}{c}\text { C\&Cs / } \\
\text { Forest- } \\
\text { country } \\
(\%)\end{array}$ & $\begin{array}{c}\text { C\&Cs / } \\
\text { FAWS- } \\
\text { country } \\
(\%)\end{array}$ & $\begin{array}{c}\text { C\&Cs/ } \\
\text { C\&Cs- } \\
\text { EU28 } \\
(\%)\end{array}$ \\
\hline France & 1699 & 1447 & $682^{\ddagger}$ & $40.2^{\ddagger}$ & 47.1 & $38.6^{\ddagger}$ \\
\hline Italy & 1084 & 601 & 340 & 31.3 & 56.5 & 19.2 \\
\hline Greece & 651 & 309 & 209 & 32.2 & $67.7^{\ddagger}$ & 11.9 \\
\hline Spain & 2598 & 1048 & 163 & 6.3 & 15.6 & 9.2 \\
\hline Bulgaria & 390 & 312 & 126 & 32.2 & 40.2 & 7.1 \\
\hline Portugal & 347 & 190 & 70 & 20.1 & 36.7 & 3.9 \\
\hline Hungary & 181 & 170 & 50 & 27.7 & 29.4 & 2.8 \\
\hline Croatia & 211 & 169 & 49 & 23.4 & 29.1 & 2.8 \\
\hline Romania & 668 & 562 & 37 & 5.5 & 6.6 & 2.1 \\
\hline Slovenia & 117 & 104 & 11 & 9.4 & 10.6 & 0.6 \\
\hline Austria & 392 & 335 & 10 & 2.4 & 2.9 & 0.5 \\
\hline Belgium & 67 & 64 & 8 & 12.4 & 13.0 & 0.5 \\
\hline Slovakia & 203 & 171 & 6 & 2.9 & 3.5 & 0.3 \\
\hline United Kingdom & 249 & 211 & 2 & 0.8 & 0.9 & 0.1 \\
\hline Sweden & $3026^{\ddagger}$ & $2124^{\ddagger}$ & 2 & 0.1 & 0.1 & 0.1 \\
\hline Luxembourg & 9 & 9 & 1 & 14.6 & 15.1 & 0.1 \\
\hline Netherlands & 34 & 31 & 1 & 1.8 & 1.9 & 0.0 \\
\hline Czech Republic & 263 & 256 & 0 & 0.2 & 0.2 & 0.0 \\
\hline Denmark & 54 & 44 & 0 & 0.4 & 0.5 & 0.0 \\
\hline Cyprus & 28 & 4 & 0 & 0.0 & 0.0 & 0.0 \\
\hline Germany & 1074 & 1014 & 0 & 0.0 & 0.0 & 0.0 \\
\hline Estonia & 216 & 193 & 0 & 0.0 & 0.0 & 0.0 \\
\hline Finland & 2277 & 2068 & 0 & 0.0 & 0.0 & 0.0 \\
\hline Ireland & 59 & 58 & 0 & 0.0 & 0.0 & 0.0 \\
\hline Lithuania & 205 & 169 & 0 & 0.0 & 0.0 & 0.0 \\
\hline Latvia & 300 & 241 & 0 & 0.0 & 0.0 & 0.0 \\
\hline Malta & 0 & 0 & 0 & 0.0 & 0.0 & 0.0 \\
\hline Poland & 894 & 830 & 0 & 0.0 & 0.0 & 0.0 \\
\hline EU28 & 17295.9 & 12733.2 & 1766.9 & 10.2 & 10.2 & 13.9 \\
\hline
\end{tabular}

tem of values of human communities at local and wider scales. The corresponding effects on forest/landscape structure/ecology are also indicated.

Currently coppice management is generally carried out according to different criteria (e.g., higher than traditional densities of standards) which were turned into regulations at different administrative levels without precise scientific support. Their implementation has resulted in the transformation of many original Italian coppiceswith-standards into stands with a high density of withering populations of stools (Becchetti \& Giovannini 1998, Del Favero 2000, Piussi 2007). Their structure does not correspond to any of the coded coppice silvicultural systems (i.e., coppice and coppice with standards - Matthews 1989, Nyland 2002, compound coppice - Nyland 2002) nor to high forest. Therefore, coppice management currently poses both ecological/technical (e.g., regeneration) and administrative challenges, such as the lack of appropriate prescriptions for the implementation of forest operations. These woodlands are known to respond inadequately to current demands in terms of fuel-wood/timber, as the high density of standard suppresses the re-sprouting ca- pacity of stools and the retained trees are not suitable for fine timber (Piussi 2007).

Other management options most frequently applied to coppice woodlands, particularly in marginal or protected areas, are non-intervention and conversion to high forest. The generalized abandonment of coppice silviculture, however, is likely to hamper the ecological functionality of woodlands, dampen tree species diversity at the patch level in mixed woodlands and in beech woodlands (Garadnai et al. 2010), raise hydrological disorder and increase wildfire risks at the landscape level (Conedera et al. 2010, Piussi \& Puglisi 2013). For most species, it is also likely to thwart the eventual reinstatement of the coppice silvicultural system as it depresses the vigour of stools (e.g., oaks - Bianchi \& Giovannini 2006, beech - Terzuolo et al. 2012). Yet, the demise of silvicultural interventions may be a necessary choice on sites with low fertility, economically marginal areas or stands degraded by fire, grazing or other disturbances. In a similar way, the conversion from coppice to high forest is not feasible on a generalized basis but rather is contingent on species composition and site fertility, and might pose future regeneration problems. It may also cause biotic homoge- 
nization at the stand level (Van Calster et al. 2007). Conversion to high forest is often a long-term process requiring relatively intensive interventions and may not always be economically sustainable for the owner (Motta et al. 2015). Yet, conversion to highforest, where the socio-economic conditions allow, might trigger functional and structural complexity. It would also add value to timber products in certain forest types (e.g., sweet chestnut coppices) which are currently not fully exploited.

\section{Approaches of modern coppice silviculture}

A range of modern approaches to coppice silviculture have been tested in Italy for more than a decade within the framework of several EU- and nationally/regionally-funded pilot projects (e.g., CHESUD, TraSFoRM, SUMMACOP, RECOFORME, ForClimadapt, SELVARBO and PProSpoT).

These include (Tab. S2, Fig. S3, Fig. S4, Fig. S5, Fig. S6 in Supplementary material) the retention of groups of standards (Savini 2010), the single-tree-oriented silviculture (Bastien \& Wilhelm 2000, Sansone et al. 2012, Manetti et al. 2016), new silvicultural systems for sweet chestnut coppices (Manetti et al. 2014), and the governo misto (mixed silvicultural system - Motta et al. 2015).

Most of these approaches are related to standard selection. Standards (i.e., selected stool shoots or seed-regenerated trees retained at each felling), traditionally evenly distributed across the stand, used to be preserved for various purposes for periods equivalent to 2 or 3 coppice cycles. Such purposes can be better understood considering the traditional way of carrying out this cultivation. Dead stools were replaced by new trees deriving from seed produced by standards as the coppice shoots were never old enough to bear seed, from layering of shoots (mainly for beech and sweet chestnut) and sometimes form artificial regeneration with seed or seedlings (sweet chestnuts and oaks). Seed production from standards was also valuable, especially in compound coppices, for pig raising. Standards could also provide beams used in rural buildings not far from the location where they would have been employed since transportation of cumbersome and heavy logs was impossible in isolated set tlements. Most of these functions have nowadays vanished, but standards can provide new services related to biodiversity maintenance and aesthetics. Therefore, modes of standard selection represent the distinctive characteristic of coppice silviculture in Italy and can be challenging. These modes not only include the number of trees selected as standards, but also concern setting the density and the spatial arrangement as well as the age/size distribution of standards within the stand, guided by informed silvicultural choices. However, the spatial arrangement of standards within the stand, in particular, al- though considered in European forestry literature (Perona 1891, Huffel 1927, Perrin 1954, Piussi \& Alberti 2015), has not been studied in depth.

All these approaches appear successful in enhancing stability of selected standards after coppice harvesting, reducing shading by the standards on the young stems, enhancing tree species diversity, increasing biodiversity by introducing new, fine grained, habitats, facilitating both marking and extraction operations, protecting soil integrity and reducing erosion, introducing a longer term perspective into the coppice silvicultural system, contributing to the improvement of the rural economy in marginal areas and reducing the ecological costs due to timber importation (Manetti et al. 2006, 2016).

\section{The landscape perspective: policy and management requirements}

The main political and socio-economic drivers descending from the commitments to EU policies influencing coppice silviculture locally in Italy include: biodiversity conservation (e.g., Habitats Directive 1992/ 43/EC), "directional flow-related" services (Costanza 2008), such as water supply, water and sediment regulation (Water Framework Directive, 2000/60/EC), obligations related to the EU-2020-2030 framework for climate and energy policies (COM/ 2014/015final), which impose a minimum $27 \%$ increase in the share of renewable energy consumption. The challenges posed by such drivers are encapsulated within the Framework Program for the Forestry Sector - Horizon 2020 which identifies four priorities to be achieved by 2020 . These include land and environment protection, maximizing the capacity for forest $\mathrm{CO}_{2}$ fixation, preservation of the integrity and health of forest ecosystems, conservation of biodiversity and landscape diversity. The framework also calls for a management of the EU forests and woodlands, including coppice woodlands, aimed at ensuring their productive, socio-economic and environmental functions in the future. Therefore, it also accounts for the legitimate profit expectations of land owners, whose role as environmental stewards has increasingly been recognized and subsidized by both agricultural and rural development policies (Warren et al. 2008).

A bottom-up response to such challenges could be effectively achieved by the combination of different, traditional (e.g., coppice selection system in beech forests Coppini \& Hermanin 2007) and novel approaches to coppice silviculture, together with both spontaneous development and conversion to high forest, at the stand and compartment levels. This would allow for an advance towards a more adaptable and multifunctional forest management in which the most suitable techniques and modes of silviculture are adjusted to each case according to specific management objectives, including the provision of com- modities and non-commercial ecological services. Moreover, considering both the environmental change perspective and socio-economic dynamics, this is in line with the so called "Options Forestry" strategy (Bormann \& Kiester 2004), that admits an uncertainty margin in connection with unpredictable changes that affect the system.

Such a combination represents an extension at the landscape level of earlier attempts to adopt a flexible silvicultural approach at the stand and sub-stand levels (Taruffi 1905, Bernetti et al. 2012). The resulting taxonomic and structural differentiation (both horizontal and vertical) obtained at the stand/compartment level, would reverberate throughout the landscape level, leading to a heterogeneous forest-landscape mosaic comprised of a range of different vegetation development stages (Buckley \& Mills 2015). Such an asset is more likely to be effective in the maintenance of ES fluxes from SPA to SBA. In particular it would ensure landscape functional connectivity by meeting the needs of an array of species of conservation concern (Mairota et al. 2006, Hermy \& Verheyen 2007, Chiarucci et al. 2008, Garadnai et al. 2010, Kopecký et al. 2013).

Yet, the operational implementation of the proposed option is complex, as, in order to respond to the socio-economic and environmental challenges affecting coppice silvicultural system, it requires:

- the existence of specialized and qualified operators in all relevant categories (work ers, forestry technicians, controllers);

- the appropriate administrative procedures to be in place;

- the adoption of innovative management models at forest and landscape levels;

- the development of scenarios simulating the potential forest dynamics at different scales (e.g., watershed).

The fulfillment of these requirements is in its infancy in Italy, where responsibilities for a number of sectors, including forestry, are delegated to regional authorities. This has contributed to a variety of (statutory) attitudes towards silviculture and forest planning and has hindered the transfer of best practices tested in pilot projects to the majority of regions. Moreover, forest management plans (FMPs) are not compulsory for forest private owners up to a minimum size of the property (50-100 ha), and when in force these plans are usually disregarded owing to market conditions. An additional difficulty lies in that harvesting operations are generally carried out by tenders rather than the owners themselves. This creates a discrepancy between long vs. short term interests associated with the woodlands. This is demonstrated by the frequency of damages to both soil and stumps caused by inexperienced workers and/or the improper use of machineries, which are often aggravated by the lack of appropriate forest road networks.

However, a few promising examples indi- 
Fig. 3 - Example of the implementation of different silvicultural options at the stand level (Photo: Terradura).

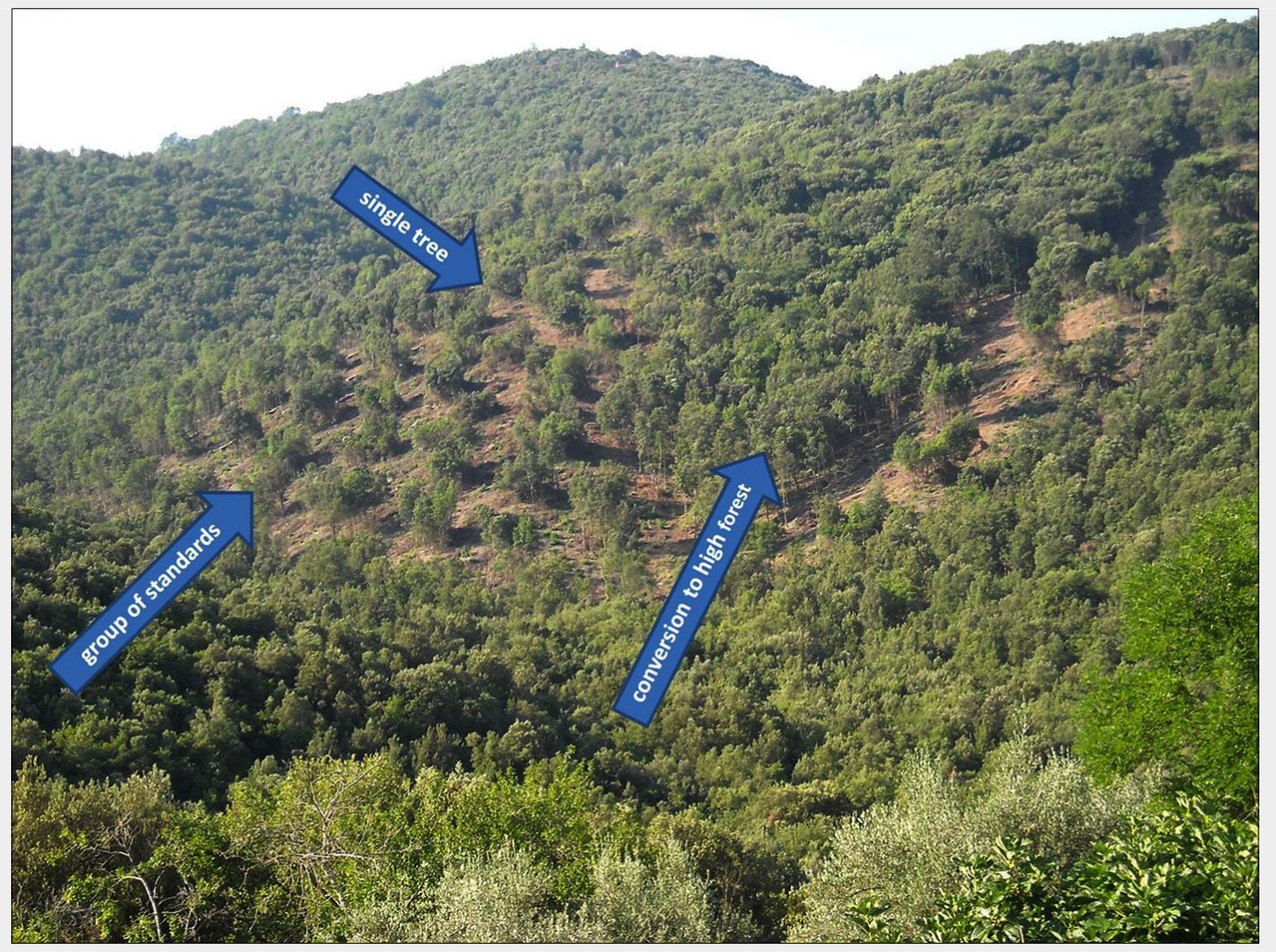

cate that progress is being made in this direction.

With regard to professional and vocational education, a number of regions (e.g., Piemonte, Lombardia, Trentino-Alto Adige, Liguria, Toscana) for a few years now offer vocational courses to obtain a license (generally mandatory to operate in public forests) as woodland operators to certify competences in both harvesting and yiarding, as much as in safety of forest works. The Regione Piemonte, in addition, offers specific intensive courses (organized in collaboration between the Institute for Timber Plants and the Environment and the University of Torino) specifically focused on the retention of groups of standards and the governo misto with a focus on the new criteria these introduce. These courses also aim at creating a synergy between the categories involved in all the phases, from the selection of crop trees/standards to logging operations. Moreover, quantitative reference models for individual species are being prepared based on empirical data.

An example of an administrative procedure that seems appropriate for integrating the concepts of ecosystem services and landscape functions into planning, management and decision-making related to coppice silviculture is the one currently applied by the Regione Umbria (Grohmann 2005). Sustainable forest coppice management is endorsed by the Regional Forest Plan which sets the objectives and prescriptions for active, cost-effective coppice management by private or public entities, and is also compliant with major EU and national regulations. Within the framework of the Regional Forest Plan, both regulations and plans concur to achieve those objectives. These plans are articulated across two interlinked levels, i.e., territorial divisions (forest plans for specific mountain areas, protected areas and watersheds), and individual or associated enterprises (FMP).

With regard to forest management, Terradura \& Consoli (2011) and Fantoni et al. (2012) have proposed innovations in FMP to incorporate novel approaches to coppice silviculture. These authors have produced FMPs allowing for the intermingling of different silvicultural prescriptions on the same management unit (Fig. 3). In these FMPs selected single trees (mostly sporadic species, valuable in terms of timber quality) and groups of standards, are managed according to an independent silvicultural schedule than that of the coppice in which they are embedded. To this end, from the operational point of view, they recommend, as far as possible, a synchronization of interventions aimed at the tending of selected trees for high quality timber production, with those of whole stand, using return periods that are submultiples of the rotation period. This can be achieved by an adjustment of the FMP to consider the periodic yield of timber products as spatially distributed across the individual estate or a network of estates, with the advantage of ensuring the constancy of the minimum commercial quantities, hence allowing for the formation of a stable market.

A prototype of a realistic approach to forest resource governance at the landscape level in Italy is that initiated in Tuscany with the creation of the first Model Forest (Casini et al. 2011) in this country. Following other long established examples across the world (e.g., the International Model Forest Network), the aim of the Model Forest of the Montagna Fiorentina is that of boosting a flexible and participatory process for the sustainable use of forest resources. In such a process, in which both traditional and novel silviculture have a role, a short forest products supply chain (sensu Masiero et al. 2013) is created with the collective efforts of social and economic forces operating on those landscapes by a number of private, public and statutory agencies. Hence, the forest landscape is considered as a whole rather than as an aggregation of discrete forest stands and holdings (Kohm \& Franklin 1997).

Finally, scenario building offers the opportunity to simulate and compare the effects of alternative management prescriptions in terms of forest harvests, the dynamics of stands naturally evolving or directed to conversion, form, size and spatial arrangement, and rotation lengths. One such attempt was carried out in a forest landscape (approx. 6000 ha) in Southern Tuscany (Colline Metallifere) dominated by neglected coppice stands and stands were tending for conversion to high forest had been initiated, and interspersed with (untended) conifer plantations (Mairota et al. 2006). The likely effects of the reinstatement of coppice management were illustrated by comparing four alternative strategies. These were based on the iterative incorporation of a number of progressively more restrictive rules accounting for bio-ecological, socio-economical and 
technical criteria. Scenario building can also be implemented by means of stochastic and spatially explicit succession/disturbance landscape simulators (Scheller \& Mladenoff 2007, Mairota et al. 2014) in order to gain a better understanding of processes and to quantify trends of proxies for ecosystem services (e.g., biomass, habitat loss, fragmentation, degradation). Another promising perspective is that of combining biomass stand/landscape models with platforms allowing for the integrated assessment of trade-offs generated by prospective management strategies at different scales on multiple ES (Frank et al. 2015). This is important to identify, quantify and communicate cause-effect relationships in order to assist decision makers to meet local scale (e.g., coppice) forest management goals within major challenges and "visions" at the global/EU scale, under global environmental change.

\section{Concluding remarks}

The coppice silvicultural system can indeed be compliant with the principles of SFM, provided that the most appropriate silvicultural approaches and harvesting techniques are implemented. As noted by Del Favero (2000), the disturbances that coppicing causes are compatible with forest resilience, and this type of forest regeneration method, which ensures more frequent revenues to owners compared to high forests, has contributed to the shaping of the Italian cultural landscapes. In addition, coppicing does not hinder biodiversity conservation as it is becoming clearer that the preservation of historical forms of management that molded forest composition may be crucial for the conservation of many rare species (Hermy \& Verheyen 2007, Mölder et al. 2014, Müllerová et al. 2015).

The examples provided also indicate that a logical and realistic hierarchy in forest planning (Baskent \& Keles 2005, Mairota \& Piussi 2009), coupled with (i) the operational incorporation of landscape ecological principles and spatial objectives (Kurttila 2001, Mendoza et al. 2005), and (ii) collective resource management programs (sensu Pretty 2003), is both necessary and a promising way to reach a balance between economic and environmental sustainability. It is also crucial to the creation of short wood-energy supply chains in rural-mountain areas. These are reputed capable (Francescato 2015) of generating social equity (via, e.g., employment, added value of products, traceability according to the EU 995/2010 Timber Regulation) and environmental benefits (e.g., reduction of $\mathrm{CO}_{2}$ emissions - Pierobon et al. 2015) at the regional scale.

Modern silviculture and landscape level governance of coppice forests, are therefore appropriate to such complex socialecological systems (sensu Ostrom 2009) for the simultaneous achievement of "the management of natural resources", "the economic needs of local communities", the maintenance of "the complex historical, traditional and actual ecological knowledge" (Cervellini 2014), while reconciling scenic aesthetic (sensu Gobster 1999) and the demands of urban communities.

\section{Acknowledgments}

We thank three anonymous referees for their critical comments, which helped us to improve the original manuscript. Earlier stages of this work have been presented as posters at the COST Action 1301 EuroCoppice Event: People and Coppice, University of Greenwich, Medway, England $5^{\text {th }}$ November, 2014 and to the Conference "Coppice forests: past, present and future", Mendel University in Brno, Czech Republic April $9^{\text {th }}-11^{\text {th }}, 2015$. For the participation in both these events, P. Mairota has received financial support from the COST Action FP 1301 "Innovative management and multifunctional utilization of traditional coppice forests: an answer to future ecological, economic and social challenges in the European forestry sector "EUROCOPPICE", http://www.eurocoppice.uni-fre iburg.de/. Authors order follows the "firstlast-author-emphasis" (FLAE) criterion (Tscharntke et al. 2007).

\section{References}

Amorini E, Fabbio G (2009). I boschi di origine cedua nella selvicoltura italiana: sperimentazione, ricerca, prassi operativa [Coppice woodlands in Italian silviculture: experiences, research, operations]. In: Proceedings of the "III National Silviculture Congress". Taormina (Messina, Italy) 16-18 Oct 2008. Accademia Italiana di Scienze Forestali, Firenze, Italy, vol. II, pp. 201-207. [in Italian]

Baskent EZ, Keles S (2005). Spatial forest planning: a review. Ecological Modelling 188: $145-$ 173. - doi: 10.1016/j.ecolmodel.2005.01.059

Bastien Y, Wilhelm GJ (2000). Une sylviculture d'arbres pour produire des gros bois de qualité [Single tree silviculture to produce valuable timber]. Revue Forestière Française 52: 407424. [in French] - doi: $10.4267 / 2042 / 5376$

Becchetti M, Giovannini G (1998). La matricinatura nei cedui di cerro: indagine in provincia di Perugia [Standards' retention in Turkey oak woodlands: survey in the Perugia province] Sherwood - Foreste e alberi oggi 34: 21-27. [in Italian]

Bernetti G, Del Favero R, Pividori M (2012). Selvicoltura produttiva. Manuale pratico [Production silviculture. A practical handbook]. Edagricole, Bologna, Italy, pp. 225. [in Italian]

Bianchi L, Giovannini G (2006). Observations on the felling of standards in oak coppices, Central Italy. Forest@ 3 (3): 397-406. [in Italian with English summary] - doi: 10.3832/eforo390-0030 397

Bormann BT, Kiester A (2004). Options forestry acting on uncertainty. Journal of Forestry 102: 22-27.

Buckley GP, Mills J (2015). The flora and fauna of coppice woods: winners and losers of active management or neglect? In: "Europe's Changing Woods and Forests: From Wildwood to
Managed Landscapes" (Kirby K, Watkins C eds). CABI, Wallingford, UK, pp. 129-139.

Casini L, Gravano E, Perulli D, Ventre T (2011). Come nasce una foresta modello [How a model forest is born. The Tuscan experience] Sherwood - Foreste e alberi oggi 171: 13-16. [in Italian]

Cervellini M (2014). Socio-ecological system of coppiced forests in the Italian Marche Region's central Apennine. PhD Thesis, School of Advanced Studies, University of Camerino, Camerino, Italy, pp. 98.

Chiarucci A, Bacaro G, Rocchini D (2008). Quantifying plant species diversity in a Natura 2000 network: old ideas and new proposals. Biological Conservation 141: 2608-2618. - doi: 10.1016/j. biocon.2008.07.024

Conedera M, Pividori M, Pezzatti GB, Gehring E (2010). II ceduo come opera di sistemazione idraulica: la stabilità dei cedui invecchiati [Coppice as an hydraulic management work: overgrown coppices stability]. In: Proceedings of the " $46^{\circ}$ Course on Culture in Ecology" (Carraro V, Anfodillo T eds). San Vito di Cadore (Belluno, Italy) 7-10 Jun 2010, University of Padua, Padua, Italy, pp. 85-96.

Coppini M, Hermanin L (2007). Restoration of selective beech coppices: a case study in the Apennines (Italy). Forest Ecology and Management 249: 18-27. - doi: 10.1016/j.foreco.2007.04. 035

Costanza R (2008). Ecosystem services: multiple classification systems are needed. Biological Conservation 141: 350-352. - doi: 10.1016/j.bio con.2007.12.020

Council of Europe (2000). European landscape convention. Firenze, Italy, pp. 4.

Del Favero R (2000). Gestione forestale e produzione legnosa a fini energetici [Forest management and energy wood production]. Sherwood - Foreste e alberi oggi 59: 5-9. [in Italian] Espinoza O, Buehlmann U, Smith B (2012). Forest certification and green building standards: overview and use in the US hardwood industry. Journal of Cleaner Production 33: 30-41. - doi: 10.1016/j.jclepro.2012.05.004

Fabbio G (2010). Il ceduo tra passato e attualità: opzioni colturali e dinamica dendro-auxonomica e strutturale nei boschi di origine cedua [Coppice between past and present: coltural options and dendro-auxonomic and structural dynamics in coppice woodlands]. In: Proceedings of the " $46^{\circ}$ Course on Culture in Ecology" (Carraro V, Anfodillo T eds). San Vito di Cadore (Belluno, Italy) 7-10 Jun 2010, University of Padua, Padua, Italy, pp. 27-45. [in Italian]

Fantoni I, Miozzo M, Rella E (2012). Forest planning and sporadic species LIFE+ PProSpoT project: first experience in Italy. Sherwood Foreste e alberi oggi 184: 9-14.

Francescato V (2015). La filiera legno-energia locale fa bene all'economia e al clima [Short wood-energy supply chain benefit both economy and environment]. Agriforenergy 3:30-32. [in Italian]

Frank S, Fürst C, Pietzsch F (2015). Cross-sectoral resource management: how forest management alternatives affect the provision of biomass and other ecosystem services. Forests 6: 533-560. - doi: 10.3390/f6030533

Garadnai J, Gimona A, Angelini E, Cervellini M, 
Campetella G, Canullo R (2010). Scales and diversity responses to management in Beech coppices of central Apennines (Marche, Italy): from floristic relevés to functional groups. Braun-Blanquetia 46: 271-278.

Gobster PH (1999). An ecological aesthetic for forest landscape management. Landscape Journal 18: 54-64.

Grohmann F (2005). Introduction à la gestion forestière en Ombrie et présentation des activités de la Région Ombrie dans le project RECOFORME [Introduction to forest management in Umbria and presentation of the activities of the Umbria Region within the framework of the RECOFORME Project]. Association Internationale Forêts Méditerranéennes, Cahier de site 5 , Marseille, France, pp. 20-22. [in French]

Hermy M, Verheyen K (2007). Legacies of the past in the present-day forest biodiversity: a review of past land-use effects on forest plant species composition and diversity. Ecology Research 22: 361-371. - doi: 10.1007/s11284-0070354-3

Howe C, Suich H, Vira B, Mace GM (2014). Creating win-wins from trade-offs? Ecosystem services for human well-being: a meta-analysis of ecosystem service trade-offs and synergies in the real world. Global Environmental Change 28: 263-275. - doi: 10.1016/j.gloenvcha.2014.07. 005

Huffel G (1927). Les méthods de l'aménagement forestier en France [The methods of forest management in France]. Annales de l'École Nationale des Eaux et Forêts et de la Station de Recherches et Expériences I, Berger-Levrault, Paris, France, pp. 229. [in French]

INFC (2007). Le stime di superficie 2005 - Prima parte" Authors: Tabacchi G, De Natale F, Di Cosmo L, Floris A, Gagliano C, Gasparini P, Genchi L, Scrinzi G, Tosi V. Inventario Nazionale delle Foreste e dei Serbatoi Forestali di Carbonio [National Inventory of Forests and of Forest Carbon Pools]. MiPAF - Corpo Forestale dello Stato - Ispettorato Generale, CRA - ISAFA, Trento, Italy, pp 409. [in Italian] [online] URL: http://www.sian.it/inventarioforestale/caricaDo cumento?idAlle $=496$

ISTAT (2014). I consumi energetici delle famiglie Anno 2013 [Energy consumption of families, Year 2013]. Istituto Nazionale di Statistica, Roma, pp. 16. [in Italian] [online] URL: http:// www.istat.it/it/files/2014/12/StatReport_Consu mi_energetici.pdf

Kohm KA, Franklin JF (1997). Creating a forestry for the $21^{\text {st }}$ century: the science of ecosystem management. Island Press, Washington, DC, USA, pp. 479.

Kopecký M, Hédl R, Szabó P (2013). Non-random extinctions dominate plant community changes in abandoned coppices. Journal of Applied Ecology 50: 79-87. - doi: 10.1111/13652664.12010

Kurttila M (2001). The spatial structure of forests in the optimization calculations of forest planning - a landscape ecological perspective. Forest Ecology and Management 142: 129-142. - doi: 10.1016/S0378-1127(00)00343-1

La Marca O, Bernetti G (2011). II ceduo in Italia aspetti colturali, produttivi, ambientali [Coppice woodlands in Italy, coltural, production and environmental aspects]. Sherwood
Foreste e alberi oggi 173: 5-14. [in Italian] Mairota P, Tellini Florenzano G, Piussi P (2006). Gestione del bosco e conservazione della biodiversità: I'analisi eco-paesistica applicata a territori boscati della Toscana meridionale [Forest management and biodiversity conservation: landscape ecological analysis of wooded lands in southern Tuscany]. In: "Selvicoltura sostenibile nei boschi cedui" [Sustainable silviculture in coppice woodlands] (Fabbio G ed). Annali C.R.A. - Istituto Sperimentale per la Selvicoltura 33: 187-230. [in Italian]

Mairota P, Piussi P (2009). Ecosistemi forestali nel paesaggio [Forest ecosystems in the landscape]. In: Proceedings of the "III National Silviculture Congress". Taormina (Messina, Italy) 16-18 Oct 2008. Accademia Italiana di Scienze Forestali, Firenze, Italy, vol. III, pp. 995-1000. [in Italian]

Mairota P, Leronni V, Xi W, Mladenoff DJ, Nagendra $H$ (2014). Using spatial simulations of habitat modification for adaptive management of protected areas: Mediterranean grassland modification by woody plant encroachment. Environmental Conservation 41: 144-156. - doi: 10.1017/S037689291300043X

Manetti MC, Amorini E, Becagli C (2006). New silvicultural models to improve functionality of chestnut stands. Advances in Horticultural Science 1: 65-69.

Manetti MC, Pelleri F, Becagli C, Conedera M, Schleppi P, Zingg A (2014). Growth dynamics and leaf area index in chestnut coppices subjected to a new silvicultural approach: singletree-oriented management. Acta Horticolturae 1043: 121-128. - doi: 10.17660/ActaHortic.2014. 1043.15

Manetti MC, Becagli C, Sansone D, Pelleri F (2016). Tree-oriented silviculture: a new approach for coppice stands. iForest (early view) doi: 10.3832/ifor1827-009

Masiero M, Andrighetto N, Pettenella D (2013). Linee-guida per la valutazione sistematica della filiera corta delle biomasse legnose a fini energetici [Guidelines for the systematic assessment of forest biomass short supply chain]. Agriregionieuropa 33: 74. [in Italian] [online] URL: http://agriregionieuropa.univpm.it/it/con tent/article/31/33/

Matthews JD (1989). Silvicultural Systems. Clarendon Press, Oxford, UK, pp. 284.

Mendoza MA, Fajardo JJ, Zepeta J (2005). Landscape based forest management, a real world case study from Mexico. Forest Ecology and Management 209 (1): 19-26. - doi: 10.1016/j.for ec0.2005.01.007

Millennium Ecosystem Assessment (2005). Ecosystems and human well-being. Island Press, Washington, DC, USA, pp. 917.

Mölder A, Streit M, Schmidt W (2014). When beech strikes back: How strict nature conservation reduces herb-layer diversity and productivity in Central European deciduous forests Forest Ecology and Management 319: 51-61.

Motta R, Berretti R, Dotta A, Motta Fre V, Terzuolo PG (2015). Il governo misto [Mixed management]. Sherwood - Foreste e alberi oggi 211: 5-9. [in Italian]

Müllerová J, Hédl R, Szabó P, (2015). Coppice abandonment and its implications for species diversity in forest vegetation. Forest Ecology and Management 343: 88-100. - doi: 10.1016/ j.foreco.2015.02.003

Nyland RD (2002). Silviculture: concept and applications ( $2^{\text {nd }}$ edn). McGraw-Hill, New York, USA, pp. 682.

Ostrom E (2009). A general framework for analyzing sustainability of social-ecological systems. Science 325: 419-422. - doi: 10.1126/scien ce. 1172133

Pentek T, Poršinsky T, Šušnjar, M, Stankić I, Nevečerel H, Šporčić M (2008). Environmentally sound harvesting technologies in commercial forests in the area of Northern VelebitFunctional terrain classification. Periodicum biologorum 110: 127-135.

Perona V (1891). Economia forestale - Trattamento dei boschi [Forest economy - Forest treatment]. Vallardi, Milano, Italy, pp. 167. [in Italian]

Perrin H (1954). Silviculture [Sylviculture]. École Nationale des Eaux et Forets, Nancy, France, pp. 411. [in French]

Pierobon F, Zanetti M, Grigolato S, Sgarbossa A, Anfodillo T, Cavalli R (2015). Life cycle environmental impact of firewood production - A case study in Italy. Applied Energy 150: 185-195. - doi: 10.1016/j.apenergy.2015.04.033

Piussi P (1979). Le traitement en taillis de certaines forêts de la Toscane du XVlème au XXème siècle [Coppice treatment of certain forests of Tuscany during the XVI and XX centuries]. Actes du Symposium International d'Histoire Forestiere. Nancy (France) 24-28 Sep 1979. ENGREF 1: 50-57.

Piussi P, Redon O (2001). Storia agraria e selvicoltura [Agrarian history and silviculture]. In: "Medievistica Italiana e Storia Agraria" (Cortonesi A, Montanari M eds) CLUEB, Bologna, Italy, pp. 179-209. [in Italian]

Piussi P (2007). Considerazioni sul governo a ceduo composto in Toscana [Considerations on the compound coppice silvicultural system in Tuscany]. Sherwood - Foreste e alberi oggi 131: 5-12. [in Italian]

Piussi P, Puglisi S (2013). Cosa non funziona nella difesa dal rischio idro-geologico nel nostro paese? Analisi e rimedi [What's wrong in the control of the hydro-geological risk in our country? Analysis and remedies]. In: Proceedings of the "Convegni Lincei". Accademia Nazionale dei Lincei, Scienze e Lettere Editore Commerciale, Roma, Italy, 270: 137-150. [in Italian]

Piussi P, Alberti G (2015). Selvicoltura generale. Boschi, società e tecniche colturali [Silviculture. Forests, societies, and coltural techniques]. Compagnia delle Foreste, Arezzo, Italy, pp. 432. [in Italian]

Pretty J (2003). Social capital and the collective management of resources. Science 302: 19121914. - doi: 10.1126/science.1090847

Sansone D, Bianchetto E, Bidini C, Ravagni S, Nitti D, Samola A, Pelleri F (2012). Tree-oriented silviculture in young coppices. Silvicultural practices to enhance sporadic species: the LIFE+ PPRoSpoT project experience. Sherwood foreste e alberi oggi 185: 5-10.

Savini P (2010). Nuove tecniche di intervento nei boschi cedui [New intervention techniques in coppice woodlands]. In: Proceedings of the " $46^{\circ}$ Course on Culture in Ecology" (Carraro V, Anfodillo T eds). San Vito di Cadore (Belluno, 
Italy) 7-10 Jun 2010. University of Padua, Padua, Italy, pp. 73-84. [in Italian]

Scheller RM, Mladenoff DJ (2007). An ecological classification of forest landscape simulation models: tools and strategies for understanding broad-scale forested ecosystems. Landscape Ecology 22: 491-505. - doi: 10.1007/s10980-0069048-4

Schultz L, Folke C, Olsson P (2007). Enhancing ecosystem management through social-ecological inventories: lessons from Kristianstads Vattenrike, Sweden. Environmental Conservation 34: 140-152. - doi: 10.1017/S0376892907003876 Spitzer L, Konvicka M, Benes J, Tropek R, Tuf IH, Tufova $J$ (2008). Does closure of traditionally managed open woodlands threaten epigeic invertebrates? Effects of coppicing and high deer densities. Biological Conservation 141: 827837. - doi: 10.1016/j.biocon.2008.01.005

Syrbe RU, Walz U (2012). Spatial indicators for the assessment of ecosystem services: providing, benefiting and connecting areas and landscape metrics. Ecological Indicators 21: 80-88. doi: 10.1016/j.ecolind.2012.02.013

Taruffi D (1905). Studio sulla produzione cedua forestale Toscana [Essay on coppice production of Tuscany]. Ramella Edizioni, Firenze, Italy, pp. 140. [in Italian]

Termorshuizen JW, Opdam P (2009). Landscape services as a bridge between landscape ecology and sustainable development. Landscape Ecology 24: 1037-1052. - doi: 10.1007/s10980008-9314-8

Terradura M, Consoli A (2011). Metodo dei lotti. Assestamento delle specie sporadiche in grado di produrre assortimenti di pregio [Method of lots. Management of sporadic tree species for the production of valuable assortments]. Sherwood - Foreste e alberi oggi 174: 45-50. [in Italian]

Terzuolo PG, Ebone A, Brenta P (2012). II faggio: Conoscenze e indirizzi per la gestione sostenibile in Piemonte [Beech: knolwedge and sustainable management options in Piemonte]. Regione Piemonte, Blu Edizioni, pp. 136. [in Italian]

Tscharntke T, Hochberg ME, Rand TA, Resh VH, Krauss J (2007). Author sequence and credit for contributions in multiauthored publications. PLoS Biology 5 (1): e18. - doi: 10.1371/journal. pbio.0050018

UN-ECE/FAO (2000). Forest resources of Europe, CIS, North America, Australia, Japan and New Zealand (TBFRA-2000). ECE/TIM/SP/17, Geneva, Switzerland, pp. 466.

Van Calster H, Baeten L, De Schrijver A, De Keersmaeker L, Rogister JE, Verheyen K, Hermy $M$ (2007). Management driven changes (19672005) in soil acidity and the understorey plant community following conversion of a coppicewith-standards forest. Forest Ecology and Management 241: 258-271. - doi: 10.1016/j.foreco. 2007.01.007

Vild O, Roleček J, Hédl R, Kopecký M, Utinek D (2013). Experimental restoration of coppicewith-standards: response of understorey vegetation from the conservation perspective. Forest Ecology and Management 310: 234-241. doi: 10.1016/j.foreco.2013.07.056

Warren J, Lawson C, Belcher K (2008). The agrienvironment. Cambridge University Press, Cambridge, UK, pp. 224.

\section{Supplementary Material}

Tab. S1 - Synoptic of changes in coppice management in connection with the system of values of human society.

Tab. S2 - Synoptic of novel approaches to coppice silviculture in Italy.

Fig S1 - Neglected coppice woodland (Photo Pelleri).

Fig. S2 - Conversion to high forest (Photo: Pelleri).

Fig. S3 - Spatial arrangement of standard trees: (a) uniform distribution; (b) group distribution (Photos: Pelleri).

Fig. S4 - Example of group standards selection in Umbria carried out during the SUMMACOP LIFE III Project. Changes in crown cover from 2001 (a) to 2010 (b) are represented.

Fig. S5 - Single tree silviculture in coppice woodlands: (a) example of target single tree in coppice (Photo woodland: Pelleri); (b) crown thinning scheme for target trees (courtesy: Mori et al. 2014).

Fig. S6 - Novel silvicultural systems for sweet chestnut coppices, structure of the stands at: (a) 10 years, (b) 30 years and (c) 50 years (Photos: Manetti).

Link: Mairota_1865@supplo01.pdf 